\title{
POSYANDU LANSIA SEBAGAI ALTERNATIF PROGRAM PELAYANAN KESEHATAN DI PANTI JOMPO DARUSSA'ADAH DAN AN-NUR DI KOTA LHOKSEUMAWE
}

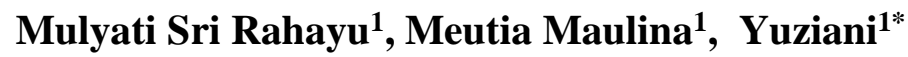

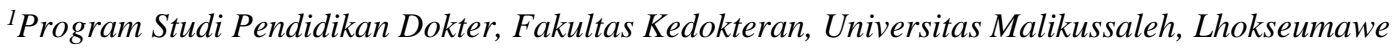 \\ *Penulis Korespodensi: yuziani_twins@yahoo.co.id
}

\begin{abstract}
Abstrak
Penduduk lansia terus meningkat dari tahun ke tahun sehingga dibutuhkan optimalisasi wahana pelayanan bagi kaum lansia seperti posyandu lansia (poslan). Tujuan pengabdian masyarakat ini adalah untuk mengatasi permasalahan program pelayanan kesehatan poslandi Panti Jompo Darussa'adah dan Panti Jompo An-Nur yang dinilai belum optimal. Selain program pelayanan poslan yang belum optimal, keterbatasan fasilitas kesehatan yang menunjang program tersebut juga masih menjadi kedala. Metode penyelesaian permasalahan dilakukan dengan membentuk kader poslan,sosialisasi poslan, pelatihan tentang tugas 5 meja (pemeriksaan fisik dan kemandirian lansia, pengisian KMS dan keterampilan laboratorium sederhana), praktek pelaksanaan poslan, penyediaan fasilitas alat kesehatan dan laboratorium sederhana serta melaksanakan kegiatan penunjang kesehatan lansia seperti senam lansia. Hasil kegiatan Iptek Bagi Masyarakat (IbM) yang dilaksanakan pada kedua mitra adalah tersedianya sistem pelayanan kesehatan 5 meja pada kedua poslan dan tersedianya kader lansia terlatih serta tersedianya sarana alat kesehatan untuk melakukan pemeriksaan kesehatan fisik dan mental emosional, tersedianya laboratorium sederhana sebagai fasilitas yang digunakan untuk deteksi dini penyakit pada lansia. Kesimpulan dari kegiatan IbM dapat meningkatkan jangkauan pelayanan kesehatan lansia dan terbentuk pelayanan kesehatan yang sesuai dengan kebutuhan lansia sehingga dapat meningkatkan derajat kesehatan lansia.
\end{abstract}

Kata kunci: Posyandu Lansia, Panti Jompo, Pelayanan Kesehatan Lima Meja

\begin{abstract}
The elderly population continues to increase from year to year, so it is necessary to optimize the health care program for the elderly such as the elderly posyandu (poslan). The purpose of the project community service is to overcome the problem of health care program poslan at Panti Jompo Darussa'adah and Panti Jompo An-Nur which considered not optimal yet. In addition to the poslan service program that has not been optimal, the limited health facilities that support the program is also still a flame. The problem solving method is done by establishing poslan cadres, poslan socialization, training on 5 table tasks (physical examination and elderly independence, KMS completion and simple laboratory skills), simulation of poslan, provision of simple medical and laboratory facilities and carrying out elderly health support activities such as Elderly gymnastics. The results of the project community activities on both partners are the availability of a five-table health care system in both posyandu and the availability of trained elderly cadres as well as the availability of health-care equipment to perform physical and emotional mental health examination, the availability of simple laboratories as facilities used for early detection of disease in the elderly. The conclusion of the project community activities can increase the reach of elderly health service and formed health service in accordance with elderly needs so as to improve elderly health degree.
\end{abstract}

Keywords: Elderly Posyandu, Nursing Home, FiveDesk Health Service.

\section{PENDAHULUAN}

Salah satu indikator keberhasilan suatu negara adalah meningkatnya usia harapan hidup penduduk (Departemen Sosial RI, 2009). Peningkatan usia harapan hidup akan menyebabkan jumlah penduduk lansia terus meningkat dari tahun ke tahun (Badan Pusat Statistik, 2011; Departemen Kesehatan RI, 2013). Jumlah penduduk lansia di Aceh dengan kisaran umur 60 tahun keatas pada tahun 2011 tercatat 270.000 lansia, kemudian meningkat pada tahun 2012 menjadi 285.476 lansia. Jumlah penduduk lansia dengan usia di atas 60 tahun di Aceh Utara pada tahun 2011 tercatat 31.566 lansia dan di Kota Lhokseumawe tercatat 12.847 lansia (Badan Pusat Statistik, 2014). Jumlah lansia yang terus meningkat menyebabkan 
angka kesakitan lansia (AKL) juga meningkat, karena semakin bertambahnya usia, fungsi organ tubuh akan semakin menurun, sehingga dapat menimbulkan berbagai masalah kesehatan dan penyakit. Masalah kesehatan lansia pada umumnya berupa malnutrisi, penurunan kognitif dan disabilitas serta penyakit kronis seperti hipertensi, penyakit jantung dan diabetes melitus (Departemen Kesehatan RI, 2013).

Data BPS tahun 2014 menyatakan Provinsi Aceh merupakan provinsi dengan AKL kedua tertinggi di Indonesia setelah provinsi Nusa Tenggara Barat dengan persentase sebesar 37,2\%.Angka Kesakitan Lansia di Provinsi Aceh lebih tinggi di daerah pedesaan $(39,64 \%)$ dibandingkan daerah perkotaan (30,23\%) (Badan Pusat Statistik, 2014). Salah satu upaya untuk menurunkan AKL adalah dengan meningkatkan derajat kesehatan lansia melalui optimalisasi posyandu lansia (poslan) (Departemen Kesehatan RI, 2006; Maas, 2008; Tabloski, 2006). Posyandu lansia merupakan wahana pelayanan bagi kaum lansia yang berfokus pada pelayanan promotif dan preventif, tanpa mengabaikan upaya kuratif dan rehabilitatif (Anderson, 2007; Notoatmodjo, 2007). Program pelayanan kesehatan poslan meliputi pemeriksaan kesehatan fisik dan mental emosional yang dicatat dan dipantau dengan Kartu Menuju Sehat (KMS) untuk mengetahui lebih awal penyakit yang diderita (deteksi dini) atau ancaman masalah kesehatan yang dihadapi (Departemen Kesehatan RI, 2003; Setiti, 2006). Berdasarkan Departemen Kesehatan RI (2006), program pelayanan kesehatan poslan meliputi pendaftaran lansia, pengukuran tinggi badan (TB) dan penimbangan berat badan (BB), pelayanan kesehatan (pengobatan kasus sederhana dan rujukan), kegiatan penyuluhan atau konseling dan penyuluhan gizi.

Terdapat beberapa kategori pada penyelenggara poslan, yaitu terdiri dari pelaksana kegiatan dan pengelola poslan. Pelaksana kegiatan merupakan anggota masyarakat yang telah dilatih menjadi kader kesehatan setempat di bawah bimbingan puskesmas. Pengelola poslan adalah pengurus yang dibentuk oleh ketua RW yang berasal dari kader PKK, tokoh masyarakat formal dan informal serta kader kesehatan yang ada di wilayah tersebut (Departemen Kesehatan RI, 2006).

Panti Jompo Darussa'adah (Mitra 1) yang berdiri sejak 1994 berlokasi di Desa Cot Girek Kandang Kecamatan Muara Dua Kota Lhokseumawe berjarak sekitar $3 \mathrm{Km}$ dari kampus Fakultas Kedokteran Universitas Malikussaleh (FK UNIMAL). Panti dipimpin oleh Tengku H. Usman Umar. Penghuni panti jompo berjumlah 60 orang lansia yang seluruhnya lansia wanita. Sebagian besar lansia berpendidikan rendah (tamatan sekolah rakyat), tidak mempunyai keluarga dan berasal dari keluarga tidak mampu. Kegiatan lansia di panti meliputi pengajian dan kegiatan ceramah keagamaan. Masalah kesehatan yang sering dialami lansia di panti jompo ini antara lain artritis reumatoid, hipertensi, diabetes melitus dan hiperurisemia.
Panti Jompo An-Nur (Mitra 2) yang berdiri sejak tahun 2004 berlokasi di Desa Ulee Blang Mane Kecamatan Blang Mangat Kota Lhokseumawe berjarak sekitar $9 \mathrm{Km}$ dari kampus . Panti dipimpin oleh H. Amri. Secara geografis panti ini berbatasan langsung dengan TK Raihanul Jannah dan Dayah AnNur. Penghuni panti jompo berjumlah 30 orang lansia wanita. Sebagian besar lansia berpendidikan rendah (tamatan sekolah rakyat), tidak mempunyai keluarga dan berasal dari keluarga tidak mampu. Kegiatan lansia di panti meliputi pengajian dan kegiatan produksi sederhana seperti membuat kerajinan tangan. Masalah kesehatan yang sering dialami lansia di panti jompo ini antara lain hipertensi, diabetes melitus dan artritis reumatoid.

Permasalahan utama yang dihadapi pada kedua mitra adalah sama yaitu belum optimalnya pelayanan kesehatan dimana belum terbentuknya pelayanan kesehatan posyandu yang dilaksanakan secara rutin, tidak adanya kader kesehatan serta tidak tersedianya fasilitas untuk mendukung pemeriksaan kesehatan tersebut seperti alat pemeriksaan tekanan darah, alat mengukur berat dan tinggi badan. Fasilitas laboratorium sederhana juga belum tersedia seperti alat pemeriksaan gula darah, kolesterol, asam urat dan hemoglobin serta pemeriksaan urin. Meskipun sebelumnya Panti Jompo Darussadah memiliki satu set pemeriksaan gula darah darah, namun sudah tidak berfungsi lagi.

Tujuan dari kegiatan pengabdian kepada masyarakat ini adalah untuk mengatasi permasalahan belum optimalnya pelayanan kesehatan posyandu lansia melalui serangkaian kegiatan meliputi pembentukan dan pelatihan kader poslan hingga kegiatan pelaksanaan pemeriksaan kesehatan bagi para lansia dengan sistem 5 meja. Pentingnya mekanisme pelayanan sistem 5 meja diharapkan akan mampu mencakup pelayanan posyandu yang sesuai program pelayanan kesehatan poslan menurut Departemen kesehatan tahun 2006 yang berfokus pada pelayanan promotif dan preventif, tanpa mengabaikan upaya kuratif dan rehabilitatif sebagai wahana pelayanan bagi kaum lansia.

\section{METODE}

Kegiatan pengabdian kepada masyarakat ini dilakukan di Panti Jompo Darussa'adah dan Panti Jompo An-Nur yang berkoordinasi dengan para kader Puskesmas wilayah masing-masing yaitu Puskesmas Muara Dua dan Puskesmas Blang Cut.

Metode yang dilaksanakan oleh tim pelaksana kegiatan pengadian kepada masyarakat melalui beberapa pendekatan yaitu:

1. Aspek program pelayanan kesehatan

Pelayanan kesehatan poslan yang belum optimal tidak terlepas dari terbatasnya jumlah kader lansia yang terlatih dan kurangnya keterampilan kader tersebut dalam melakukan administrasi poslan, memberikan informasi kesehatan pada lansia dan melakukan kegiatan poslan sesuai dengan sistem 
pelayanan kesehatan 5 meja. Pendekatan ini dilaksanakan melalui :

a. Membentuk kader poslan dan sosialisasi tentang pentingnya poslan pada kader yang akan dibentuk

b. Penyuluhan dan pelatihan tentang tugas 5 meja yang ada di poslan

Pada kegiatan ini kader lansia akan dijelaskan tentang cara pencatatan/registrasi data demografi dan data kesehatan lansia (meja 1), pemeriksaan kesehatan diantaranya mengukur TB, BB dan indeks massa tubuh, memeriksa tekanan darah, denyut nadi dan suhu, yang hasilnya dicatat pada kartu status kesehatan lansia dan penjelasan tentang cara membaca dan mengisi KMS, penilaian indeks katz/kemandirian lansia (meja 2), pemeriksaan hemoglobin, kadar gula darah, kadar kolesterol total, kadar asam urat, protein urin dan glukosa urin (meja 3), penyuluhan dan pemberian makanan tambahan lansia (meja 4) dan pelayanan kesehatan/pengobatan lansia (meja 5).

c. Praktek pelaksanaan poslan

Pada praktek pelaksanaan poslan masingmasing kader lansia yang telah dilatih akan didampingi oleh mahasiswa dan tenaga kesehatan. Masing-masing kader akan mengamati dan mempraktekkan tugasnya sesuai dengan tugas dari 5 meja.

2. Aspek sarana dan prasarana penunjang pelayanan kesehatan

Ketidaktersediaaan sarana dan prasarana penunjang pelayanan kesehatan pada kedua mitra menjadi salah satu penyebab belum optimalnya pelayanan kesehatan poslan yang sesuai standar Departemen Kesehatan. Menurut Departemmen Kesehatan RI tahun 2006 disebutkan bahwa standar program pelayanan kesehatan poslan meliputi pendaftaran lansia, pengukuran tinggi badan (TB) dan penimbangan berat badan (BB), pelayanan kesehatan (pengobatan kasus sederhana dan rujukan), kegiatan penyuluhan atau konseling dan penyuluhan gizi.

Kegiatan ini dilaksanakan melalui :

a. Penyediaan fasilitas alat kesehatan dan laboratorium sederhana

Kegiatan ini dilakukan dengan pemenuhan fasilitas alat kesehatan meliputi stetoskop, sphygmomanometer, termometer, timbangan dewasa, alat pengukur tinggi badan masingmasing sebanyak 1 set. Fasilitas laboratorium berupa 1 unit alat pemeriksaan hemoglobin, kadar gula darah, kolesterol total serta kadar asam urat. Satu set pemeriksaan urin pemeriksaan glukosa pada urin sebagai deteksi awal adanya penyakit diabetes melitus dan pemeriksaan protein pada urin sebagai deteksi awal adanya penyakit ginjal.

b. Kegiatan penunjang kesehatan lansia
Kegiatan dilakukan dengan melatih kader lansia untuk dapat menjadi instruktur senam lansia, sehingga kegiatan ini dapat rutin dilaksanakan di kedua mitra guna meningkatkan kebugaran lansia. Kegiatan ini didukung dengan penyediaan fasilitas perangkat elektronik berupa 1 unit speaker USB yang menunjang kegiatan senam lansia.

Bagian akhir dari solusi penyelesaian permasalahan mitra adalah evaluasi pelaksanaan dan keberlanjutan program. Evaluasi dilakukan oleh tim IbM dan pihak untuk menilai dan memantau mitra demi keberlanjutan program. Partisipasi puskesmas untuk ketersediaan kader tenaga kesehatan dan obatobatan juga merupakan bentuk dukungan terhadap keberlanjutan poslan di kedua mitra.

\section{HASIL DAN PEMBAHASAN}

Hasil yang telah dicapai melalui program kegiatan ini adalah sesuai dengan target yang telah direncanakan sebelumnya yaitu:

1. Pembentukan kader poslan dan sosialisasi program poslan

Kegiatan pembentukan kader di Panti Jompo Darussa'adah dan Panti Jompo An-Nur diikuti oleh pimpinan panti, kader panti, kader puskesmas, kader mahasiswa. Sosialisasi program dismpaikan oleh tim pengabdian dosen FK Unimal dalam bentuk presentasi tentang solusi yang ditawarkan terkait permasalahan belum optimalnya pelayanan kesehatan poslan dikedua panti. Solusi yang ditawarkan oleh tim berupa peningkatan pelayanan kesehatan lansia dan ketersediaan fasilitas yang menunjang pelayanan kesehatan dikedua panti. Pihak panti menyetujui untuk memfasilitasi ketersediaan ruangan poslan dan kader yang akan dilatih. Kader dari setiap panti terdiri dari tiga orang yang akan membantu pelayan kesehatan di poslan tersebut.

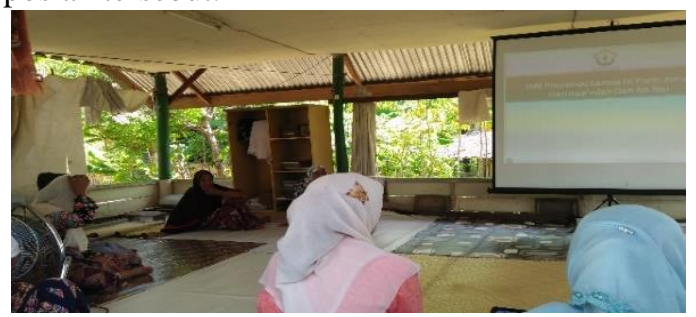

Gambar 1 . Pembentukan kader poslan, sosialisasi program poslan, penyuluhan dan pelatihan tugas 5 meja

2. Penyuluhan dan Pelatihan tentang tugas 5 meja yang ada di poslan.

Pada kegiatan ini telah dilakukan penyuluhan dan pelatihan kader poslan tentang cara pencatatan/registrasi data demografi dan data kesehatan lansia (meja 1), pemeriksaan kesehatan diantaranya mengukur TB, BB dan indeks massa tubuh, memeriksa tekanan darah, denyut nadi dan suhu, dan penyelasan tentang cara menbaca dan 
mengisi KMS serta penilaian index katz/ kemandirian lansia (meja 2), pemeriksaan hemoglobin, kadar gula darah, kadar kolesterol total, kadar asam urat, protein urin dan glukosa urin (meja 3), penyuluhan dan pemberian makanan tambahan lansia (meja 4) dan pelayanan kesehatan/pengobatan lansia (meja 5).

3. Simulasi senam lansia

Kegiatan dilakukan dengan melatih kader lansia untuk dapat menjadi instruktur senam lansia, sehingga kegiatan ini dapat rutin dilaksanakan di kedua mitra guna meningkatkan kebugaran lansia. Kegiatan ini telah didukung dengan penyediaan fasilitas perangkat elektronik yang menunjang kegiatan senam lansia. Pelaksanaan simulasi senam lansia telah dilaksanakan di kedua Panti jompo dengan melibatkan semua kader dan lansia dipanti jompo tersebut.

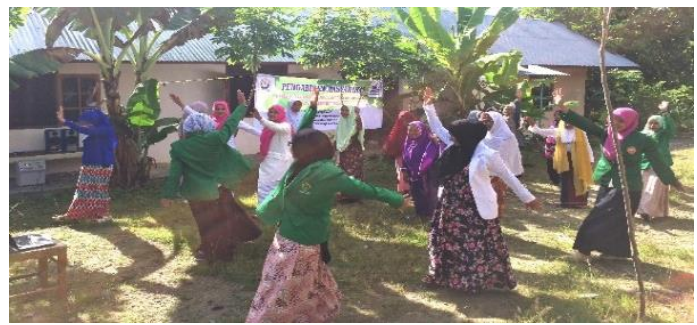

Gambar 2 .Simulasi senam lansia

4. Simulasi program poslan sistem 5 meja Posyandu lansia di kedua Panti Jompo dilaksanakan diruangan yang telah difasilitasi oleh panti dan telah disusun 5 meja beserta kebutuhan pelayanan kesehatan meliputi fasilitas alat kesehatan dan laboratorium sederhanan untuk menunjang pelayanan kesehatan poslan. Pada praktek pelaksanaan poslan masing-masing kader lansia yang telah dilatih didampingi oleh mahasiswa dan tenaga kesehatan. Masing-masing kader akan mengamati dan mempraktekkan tugasnya sesuai dengan tugas dari 5 meja.

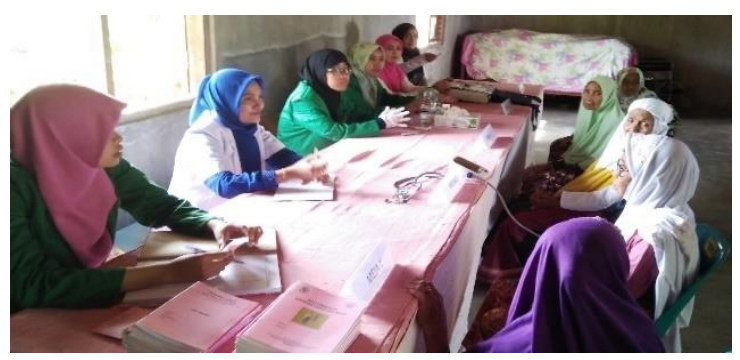

Gambar 3. Simulasi program poslan sistem 5 meja

Pentingnya aplikasi sistem 5 Meja didalam kegiatan pengabdian kepada masyarakat ini adalah untuk adanya satu program kegiatan yang langsung beraplikasi kepada masyarakat secara terstruktur dan berkesinabungan untuk pelayanan kesehatan terutama para lansia.

Posyandu Lansia (Effendi dan Nasrul, 1998), merupakan pusat kegiatan masyarakat dalam upaya pelayanan kesehatan dan keluarga berencana. Posyandu adalah pusat pelayanan keluarga berencana dan kesehatan yang dikelola dan diselenggarakan untuk dan oleh masyarakat dengan dukungan teknis dari petugas kesehatan dalam rangka pencapaian Norma Keluarga Kecil Bahagia Sejahtera (NKKBS).

Program pelayanan kesehatan dan pengadaan fasilitas penunjang poslan yang telah diimplementasikan ini diharapkan dapat meningkatkan jangkauan pelayanan kesehatan lansia di kedua mitra dan terbentuk pelayanan kesehatan yang sesuai dengan kebutuhan lansia sehingga dapat meningkatkan derajat kesehatan lansia. Selain itu diharapkan dapat meningkatkan peranserta kader lansia dalam pelayanan kesehatan serta meningkatkan komunikasi antara lansia di panti jompo tersebut.

Pelayanan kesehatan 5 meja yang telah dilaksanakan meliputi registrasi lansia, pemeriksaan fisik dan mental seperti pengukuran TB, BB dan tekanan darah, pencatatan dan pengisian KMS, penyuluhan kesehatan dan pemberian makanan tambahan serta pengobatan. Selain itu juga telah dilakukan kegiatan untuk menunjang kesehatan seperti olahraga senam lansia untuk meningkatkan kebugaran lansia. Untuk kelancaran pelaksanaan kegiatan poslan telah disediakan sarana dan prasarana penunjang yaitu tempat kegiatan (gedung/ ruang atau tempat terbuka), meja dan kursi, alat tulis, buku pencatatan kegiatan, timbangan dewasa, meteran pengukuran TB, stetoskop, termometer, peralatan laboratorium sederhana, dan KMS lansia, sehingga seluruh rangkaian kegiatan poslan tersebut diharapkan telah memenuhi standar program pelayanan poslan sesuai dengan Depkes RI tahun 2006.

Secara garis besar, menurut Depkes RI (2006), tujuan pembentukan posyandu lansia sebagai berikut :

1. Meningkatkan jangkauan pelayanan kesehatan lansia di masyarakat, sehingga terbentuk pelayanan kesehatan yang sesuai dengan kebutuhan lansia

2. Mendekatkan pelayanan dan meningkatkan peran serta masyarakat dan swasta dalam pelayanan kesehatan disamping meningkatkan komunikasi antara masyarakat usia lanjut.

Terpenuhinya target luaran dari kegiatan IbM ini ditunjukkan melalui tersedianya pelayanan kesehatan lansia dan adanya fasilitas sarana dan prasaranan yang menunjang pelayanan kesehatan yang sangat dibutuhkan pada kedua panti.

Senam lansia adalah serangkaian gerak nada yang teratur dan terarah serta terencana yang diikuti oleh orang lanjut usia yang dilakukan dengan maksud meningkatkan kemamp meningkatkan kemampuan fungsional raga untuk mencapai tujuan tersebut.Manfaat dari olahraga bagi lanjut usia menurut Nugroho (2000) antara lain :

1. Memperlancar proses degenerasi karena perubahan usia. 
2. Mempermudah untuk menyesuaikan kesehatan jasmani dalam kehidupan (adaptasi)

3. Fungsi melindungi, yaitu memperbaiki tenaga cadangan dalam fungsinya terhadap bertambahnya tuntutan, misalya sakit. Pad(a lanjut usia terjadi penurunan masa otot serta kekuatannya, laju denyut jantung maksimal, toleransi latihan, kapasitas aerobik dan terjadinya peningkatan lemak tubuh. Olahraga seperti senam lansia dapat mencegah atau melambatkan kehilangan fungsional tersebut. Berbagai penelitian menunjukan bahwa latihan/olah raga seperti senam lansia dapatmengeliminasi berbagai risiko penyakit seperti hipertensi, diabetes melitus, penyakit arteri koroner dan kecelakaan. (Darmojo, 2006) sehingga sangat diharapkan para lansia dapat melaksanakan kegiatan penunjang ini.

Terpenuhinya target kegiatan penunjang bagi lansia adalah telah terlaksananya senam untuk lansia melalui pelatihan kader sebagai instruktur senam dan tersedianya alat penunjang untuk melaksanakan senam yang difasilitasi tim pengabdian untuk melaksanakan kegiatan tersebut.

\section{KESIMPULAN}

Kegiatan pengabdian kepada masyarakat ini telah memfasilitasi pembentukan kader poslan di Panti Jompo Darussa'adah dan Panti Jompo An-Nur. Melalui sosialisasi program poslan di kedua panti jompo tersebut juga sudah terlatihnya kader poslan tentang pencatatan/registrasi data kesehatan lansia serta pemeriksaan fisik umum/kemandirian lansia serta pelatihan pengisian KMS dan keterampilan laboratorium sederhana di kedua panti jompo.

Posyandu lansia di kedua panti jompo telah dilengkapi fasilitas fasilitas alat kesehatan dan laboratorium sederhana serta fasilitas perangkat elektronik untuk menunjang kegiatan senam lansia. Sehingga telah tercapainya tujuan akhir program pengabdian masyarakat ini, melalui pelaksanaan simulasi program posyandu lansia dengan sistem 5 meja dan ketersediaan fasilitas penunjang pelayanan kesehatan di kedua panti jompo.

Upaya keberlanjutan program posyandu lansia melibatkan dukungan dan peran aktif yang sinergi antara pihak Panti Jompo, Fakultas Kedokteran, Dinas kesehatan, Puskesmas dan organisasi sosial lainnya seperti Health Education and Promotio (HEP). Pihak Fakultas dan Puskesmas berpartisipasi melalui ketersedian tenaga kesehatan dan obat-obatan. Perhatian dinas kesehatan yang diberikan dalam bentuk pengawasan dan evaluasi kegiatan, sedangkan Organisasi HEP membantu terlaksananya program dengan tersedianya kader. Pihak panti jompo berpartisipasi dalam pemeliharaan fasilitas alat kesehatan dan alat pendukung lainnya, sehingga pelayanan kesehatan lansia dan fasilitas sarana dan prasaranan yang menunjang pelayanan kesehatan bagi lansia akan terus optimal.

\section{DAFTAR PUSTAKA}

Anderson, MA. (2007). Caring for older adults holistically. $4^{\text {th }}$ Edition. Philadelphia: FA Davis Company.

Badan Pusat Statistik. (2011). Statistik penduduk lanjut usia 2011. Diunduh 11 April 2016 dari: http://www.bps.go.id/hasil_publikasi/stat_lansi a_2011/files/search/searchtext.xml

Badan Pusat Statistik. (2014). Statistik penduduk lanjut usia 2014. Diunduh 30 Maret 2016 dari: http://www.bps.go.id

Departemen Kesehatan Republik Indonesia. (2003). Pedoman pengelolaan kesehatan di kelompok usia lanjut. Jakarta: Departemen Kesehatan Republik Indonesia.

Departemen Kesehatan Republik Indonesia. (2006). Pedoman pelatihan kader kelompok usia lanjut bagi petugas kesehatan. Jakarta: Direktorat Kesehatan Keluarga.

Departemen Kesehatan Republik Indonesia. (2013). Gambaran kesehatan lanjut usia di Indonesia. Jakarta: Departemen Kesehatan Republik Indonesia.

Departemen Sosial Republik Indonesia. (2009). Dukungan kelembagaan dalam kerangka, peningkatan kesejahteraan lansia. Jakarta: Kantor Urusan Pemberdayaan Lansia Departemen Sosial Republik Indonesia.

Darmojo R.B. (2006). Buku Ajar Geriatri. Edisi ke-3, Balai Penerbit Fakultas Kedokteran Universitas Indonesia. Jakarta.

Effendi \& Nasrul, (1998). Dasar-Dasar Perawatan Kesehatan Masyarakat, Jakarta. EGC.

Maas, ML. (2008). Asuhan keperawatan geriatrik, diagnosis NANDA, kriteria hasil NOC, intervensi NIC. Jakarta: EGC.

Notoatmodjo, S. 2007. Kesehatan masyarakat ilmu dan seni dan pendidkan dan perilaku kesehatan. Jakarta: Rineka Cipta.

Nugroho, W. (2000), Keperawatan Gerontik. Edisi ke2, Penerbit EGC, Jakarta.

Setiti, S.G. (2006). Pelayanan lanjut usia berbasis kekerabatan (studi kasus pada lima wilayah di Indonesia). Diunduh 3 Mei 2016 dari: http://www.depsos.go.id

Tabloski, PA. (2006). Gerontological nursing. New Jersey: Pearson Prentice Hall. 